\title{
THE SPATIALITIES OF ACTUALLY EXISTING NEOLIBERALISM IN GLASGOW, 1977 TO PRESENT
}

\author{
by \\ Mark Boyle, Christopher McWilliams and Gareth Rice
}

BOYLE, M., McWILLIAMS, C. and RICE, G. (2008): 'The spatialities of actually existing neoliberalism in Glasgow, 1977 to present', Geografiska Annaler: Series B, Human Geography 90 (4): 313-325.

ABSTRACT. Resisting the temptation to view the neoliberalization of urban policy as unidirectional, pure and hegemonic, this article sets out to make sense of the biography of the process in one city in particular, Glasgow. It attempts to organize, marshall and discipline existing literature on the city's local economic, planning and welfare policies, so as to offer a longitudinal reading of Glasgow's encounter with neoliberal reform across the period 1977 to the present. The article questions whether Glasgow's new political-economic dispensation is capable of stabilizing local capitalist social relations and securing a new local growth trajectory. Space emerges as a critical part of the story. Neoliberalism has interlaced with historical structures, ideologies and policies to produce a range of new hybrid and mutant socio-spatial formations and because it does not amount to a pure and coordinated project these socio-spatial formations contradict and collide as often as they reinforce. Precisely because of the contingent and complicated spatialities it deposits, neoliberalism will continue to struggle to secure a regulatory framework capable of stabilizing local accumulation indefinitely.

Key words: Glasgow, actually existing neoliberalism, entrepreneurialism, path dependency, partnerships, Third Way, regulation.

The debate on neoliberalism and the city has only just begun. Conceptual, methodological, and empirical issues remain to be explored: our understanding of 'market rule', its strategic and ideological foundations, its institutional manifestations, its contradictions and variegated local consequences remain seriously incomplete. Whilst these challenges arguably obtain at all spatial scales, cities, and city regions represent key spatial arenas in which they may be confronted as the urbanisation of neoliberalism proceeds.

(Brenner and Theodore 2005, p. 107)

\section{Introduction}

The rise and rise of the concept of neoliberalism has been underpinned by a particular historiography (Harvey 2005, 2006). Under the tutelage of, first, von Hayek and, second, Friedman, neoliber- alism is understood to have come to prominence as something of a thought experiment. A utopian intellectual movement centred around the University of Chicago was then born, which sought to diagnose the failings of Keynesian economics and to remedy these failings by placing individual liberty, deregulation, free markets, free trade, private property rights and entrepreneurial freedoms at the heart of national, regional and local growth strategies. Piloted first in Chile under Pinochet and exported as part of the World Bank and IMF Structural Adjustment Programmes, this proto-neoliberalism finally escaped the laboratory and came to fruition in the advanced capitalist heartland in the late 1970s and early 1980s. Brokered by Thatcherism and Reaganism, neoliberalism secures hegemonic status and becomes an article of faith in Western political economy. Today, neoliberal reform is found everywhere and at every scale.

Life of course is never quite so simple. The extent to which the term 'neoliberalism' may be said to map on to any meaningful empirical referent is now becoming a matter for debate. A palpable mood of hostility against those who might use and abuse the notion has simultaneously grown. According to Hackworth and Moriah (2006), sceptics question the integrity of the concept of neoliberalism on the grounds that as it has become embedded in nations, regions and cities in contextually specific ways, neoliberal doctrine has become hybridized and has crystallized into complex and mutant 'actually existing' forms. In addition, these forms often contradict the principles from which they derive and in any event run in parallel with other ideologies and programmes of reform. A removal of the term from the academic vocabulary seems the only way to overcome glib and fruitless characterizations of contemporary political economy.

This article continues to see value in persisting with the label 'neoliberalism' but does take seriously the need to examine the complex ways in which the doctrine has taken root in specific locales, has metamorphosed with different local path dependen- 
cies, and has become entangled with other ideologies and reform agendas. Its focus is upon the neoliberalisation of the institutions of urban governance specifically. If David Harvey's (1989) depiction of a shift in the governance of advanced capitalist cities - from urban managerialism to urban entrepreneurialism - posted notice of the beginnings of a process, then arguably it has been in the work of Brenner and Theodore $(2002,2005)$ that the actually existing neoliberal urbanisms which have resulted have been best conceptualized and tracked.

According to Brenner and Theodore (2002, 2005), neoliberalism has pushed cities to the forefront of the drive for national competitiveness. Whether it be in terms of the filtering of national and regional programmes of state reform into specific cities, or reforms beginning and ending in the city itself, neoliberal thinking has become woven into localities in different ways as a consequence of their unique social, cultural, economic, political and institutional histories. A period of creative destruction has then ensued in which neoliberalism has junked, metamorphosed and recalibrated existing institutions, and erected many new ones. Mapping and explaining the genesis, trajectories and path dependencies of different urban-based neoliberal experiments has emerged as a key research agenda.

Resisting the temptation to view the neoliberalization of urban policy as unidirectional, pure and hegemonic, this article sets out to make sense of the biography of the process in one city in particular, Glasgow. Glasgow, of course, has captured the attention of a raft of researchers who have come to regard it as a model laboratory within which processes of deindustrialization and urban regeneration might be illuminated. Whether it be in terms of Checkland's (1976) use of the myth of the Upas Tree, Keating's (1988) motif of the 'City that refused to die', Boyle and Hughes' (1994) deployment of the "urban managerialism to urban entrepreneurialism binary', Bianchini and Parkinson's (1993) depiction of the 'cultural and creative city', Mooney and Danson's (1997) invocation of the 'dual city' metaphor, MacLeod's (2002) use of the concept of 'urban revanchism', or Turok's (2004) operationalization of the notion of the 'city region', Glasgow's actually existing neoliberal urbanism has been decoded in multiple ways, through the lens of multiple theoretical and conceptual frameworks, which slide over one another, sometimes coming into harmony with each other, more often than not sitting in an uneasy alliance or even coming into conflict.
There is a danger that a piling up of studies, operating with different theoretical agendas, and focusing upon discrete and partial chunks of the whole story, may in fact be clouding understanding of the neoliberalization of local institutions and policy agendas. By offering a reading of Glasgow's encounter with neoliberal reform across the period 1977 to present, this article seeks to organize, marshall and discipline the insights produced by work to date. The article is structured around four principal sections. First, we outline the key historical conditions that helped shape Glasgow's rise to prominence as an early pioneer of proto-neoliberalism in the British context. This is then followed by three sections looking at neoliberal doctrine and economic policy, planning and welfare respectively. We conclude by reflecting upon the degree to which Glasgow's actually existing neoliberalism is capable of securing local capitalist social relations and a new local growth trajectory. Introducing the concept of the spatiality of actually existing neoliberal urbanism, we will conclude that spatial contradictions might conspire to undermine the capacity of emerging state-economy relations to serve as a durable regulatory apparatus.

\section{The path dependencies shaping Glasgow's encounter with neoliberalism}

Caught up in the Thatcher project, Glasgow was heavily impacted by the collapse of the Fordist Keynesian compromise and the rolling back of the British state in the late 1970s and early 1980s. At the same time however, it has also emerged as a leading pioneer of neoliberal experimentation. While this has undoubtedly involved the imposition of Scottish (Scottish Office, Scottish Executive, and now Scottish Government) and Britishbased policy initiatives, arguably it has been the city council itself that has spearheaded the turn towards the market for which the city has become famous.

Between 1933 and 1977 the Labour Party had control of, first, Glasgow Corporation and from 1975 Glasgow District Council. This elongated term of office was to come to an abrupt halt in 1977 when, remarkably, a coalition led by the local Conservative Party secured power. Stunned by voter apathy and antagonism, and losing some of their more senior members, the local Labour Party entered a period of reflection. Deciding against direct confrontation with the Thatcher project, Glasgow's Labour Group decided that it might be more astute to keep ahead of the rest of the field and launched a 
pre-emptive strike. It was against this backdrop that Glasgow became one of the first British cities to experiment with neoliberal doctrines and to reflect upon their meaning and implications for urban management and growth specifically. Well in advance of the birth of 'New Labour' nationally, Glasgow's Labour Party re-emerged in 1980 with a new policy agenda and secured power once more.

In what sense can one detect a path dependency to the city's early experimentation with neoliberal urbanism? Arguably, three historical factors combined to shape the policies and practices of the rejuvenated Labour Party from 1980.

1. The city had encountered substantial deindustrialization. Checkland (1976) famously deployed the concept of the Upas Tree to undergird the extent to which the decline of the city's narrow economic base, structured as it was on shipbuilding and heavy engineering, had served to pull the city more generally into economic crises. Underinvestment, disinvestment, capital flight and unemployment came to blight the local economy. No matter which cocktail of measures were used, Glasgow topped virtually every national survey of deprivation and poverty. Reading their rejection at the polls as a reaction to Glasgow's deep experience of deindustrialization and the failure of politicians to address decline, New Labour in the city had an especially heightened sensitivity to the imperative of promoting local economic growth.

2. Glasgow was a city that had also been profoundly wounded by the failures of the post-war planning system. Throughout the twentieth century but especially from 1945 onward, the Labour Party's priority had been to remedy the problem of significant overcrowding in the city's core. 'Slum clearance' became the mantra of the times and under the umbrella of the ever expanding Keynesian welfare state, inner city clearance paved the way for a massive expansion of new build within the social rented sector. A hybrid outcome of both the Clyde Valley Regional Plan (1946) and the Bruce Plan (1949), inner city demolition, peripheral housing estates, new towns and the high-rise solution were to substantially transform the city's landscape.

Glasgow's encounters with the post-war modernist and utopian planning system has had three major implications for the city's subsequent political development. First, the policy of overspill to the various new towns surrounding the city was socially differentiated. Those who relocated out of the city to the new greenfield sites tended to be among the city's younger, more able and more skilled population. This selective migration process was to leave behind a disproportionate concentration of elderly, unemployed and people with limiting long-term illnesses.

Second, overspill was to reduce the city's population from its maximum of 1.2 million in 1920 to the new low of 680000 by 1980 . In itself mourned as a sign of the decline of the city and an indication of its loss of prestige, population decline was also to have important implications for the local tax base. Entering into the 1980s, at precisely that point in time when it was being subjected to fiscal constraints imposed by the British state, Glasgow itself was unable to find the resources within itself to deal with the spiral of decay and the social deprivation which accompanied it.

Finally, post-war planning had served to alienate the local population from a sense of democratic participation in local politics. At first a utopian landscape of hope and ambition, peripheral housing estates in particular quickly became problems in and of themselves. Occupying monotonous and bleak landscapes, removed from the amenities of the town centre, and lacking the basic services required of everyday life, communities failed to germinate and prosper. The utopian dream had given way to a dystopian nightmare and, in the words of Richard Sennett (2003), the state had unwittingly become an agent of 'compassionate wounding'. Citing the overly centralized and remote planning machinery as the second key reason why the local electorate had not voted strongly enough for them, the Labour Party sought to embark upon a decentralization of decision-making and a greater sense of community consultation with, participation in, and even ownership over, the delivery of local welfare.

3. Finally, Glasgow's turn to a new period of politics in the early 1980s also requires an appreciation of the degree to which the city, according to some, had suffered from a particularly poor image. In many senses this poor image was intimately tied to the city's economic demise. Glasgow was a bleak industrial wasteland with little of aesthetic beauty to commend itself. In addition, some perceived the city's reputation as a centre for working-class politics (the Red 
Clydeside myth), as a city noted for its violence and gang turf warfare (no mean city and the razor gangs of the 1930s), and as a city suffering from religious bigotry and prejudice (encapsulated in the Rangers FC (Protestant) and Celtic FC (Catholic) football derby) as harmful images. If any deindustrialized city was to find it difficult to compete for footloose capital, besmirched by particularly strong negative stereotypes, Glasgow would find it almost impossible.

\section{The rise of local economic policy: the turn to local land, property and consumer markets}

Glasgow's early encounters with local economic policy were brokered by two new institutions:

- The City Council established an Economic Development Committee (EDC) which, while receiving under 1 per cent of the council's budget, was a symbolic statement of intent. The EDC conducted analyses of the city's economy and sought to assist local firms particularly with market research. It established relationships with other Council departments with potentially important economic roles, in particular in the areas of culture, the arts and leisure.

- Glasgow Action was formed, a group consisting of local elites drawn from a range of public sector and private sector organizations. Glasgow Action had no statutory authority and no direct political power, but it was to prove influential as a think-tank of sorts.

In 1984, Glasgow Action commissioned international consultants McKinsey and Co. (1984) to undertake a review of Glasgow's economic position, prospects and policy options. McKinsey and Co. concluded that Glasgow's deindustrialization was irreversible and that the city's future depended upon it emerging as a post-industrial service economy. Capturing mobile capital in the service sector, both public and private, was of critical importance. Against this backdrop, Glasgow City Council and Glasgow Action slowly came to realize the importance of city marketing.

In the period when they were out of office (1977-1980), local councillors had also visited similar rustbelt and smokestack cities in the USA including Minneapolis, Baltimore and Pittsburgh. Impressed by the post-industrial renaissance these cities were experiencing, the City Council recog- nized the importance of transforming the image of the city and putting it back on the investment map. League tables, ranking cities on the basis of quality of life such as the Rand McNally rankings, were given serious attention and were far from superfluous. Moreover, insofar as cultural and leisure amenities could be constructed so as to accomplish city 'makeovers', they too were seen as important tools in the selling of the city as well as constituting a new economic sector in and of themselves.

It is important to appreciate that in the decade 1980 to 1990 Glasgow City Council had more of an orientation towards neoliberalism than a coherent neoliberal agenda as such. Exposed to Thatcher's implementation of full-fledged roll-back neoliberal reform at the national level, and constrained by the rules of ultra vires, the local council had only limited options available to it to counter deindustrialization. Indeed, throughout this period, the central purpose of the council remained the provision and management of local service provision, in particular housing; albeit in a reformed way. Alongside housing, nevertheless, local economic development began to appear on the agenda and symbolically important postures towards the market were to become routine. In addition, place marketing did begin to divert more local resources from welfare to local economic development.

Starting in 1983 with the opening of the Burrell Collection, civic boosterism did indeed become the hallmark of Glasgow's approach to urban regeneration. Among the various activities undertaken were Mayfest (1981), the Glasgow's Miles Better Campaign (1984), the Glasgow Garden Festival (1988), the European City of Culture event (1990), the building of a new Concert Hall (1990), the Glasgow's Alive promotion (1997), the City of Architecture event (1999) and the Glasgow: Scotland with Style campaign (2003). In 2012, Glasgow will host the Commonwealth Games. Glasgow has launched and invented every conceivable form of place marketing from the construction of cultural attractions, to the hosting of hallmark events, from street lighting to the renovation of public space, from slogans to formal advertising campaigns in the UK press and beyond, and so on.

By the late 1980s, it looked as if these campaigns were beginning to have some success. Place marketing was putting the city back on the investment map. In 1988, the local tabloid, The Evening Times, proudly announced that Glasgow was 'Fat City' with over $£ 800$ million of inward investment. By 1989 this had grown to become the $£ 1$ billion city 
and by 1990 the Council referred to Glasgow as the $£ 2.5$ billion city - more investment than any other city in Britain outside of London. And so the city was gradually turned from an area of blight to one of reinvestment by property capital, retailers, hoteliers and leisure capital. Much of this investment came from finance capital, especially pension funds and insurance companies based in London and abroad.

The city centre was to be the primary beneficiary of Glasgow's attempt to secure a new niche in the international division of labour. Up until the early 1980s, Glasgow city centre symbolized the general demise of Glasgow itself. As the city progressively lost its manufacturing base, so too did its city centre take on the appearance of a run-down, 'smokestack' rustbelt downtown. The streets were shabby, the infrastructure looked in need of major investment, higher quality shops were being replaced by bargain outlets catering for the lower end of the market, and crime, poor environmental quality and congestion became common problems.

With the birth of the 'New Glasgow', Glasgow city centre began to flourish. The McKinsey and Co audit set out a vision through which the city centre was to be regenerated. Three concepts were to drive the plan. First, Buchanan Street was to be promoted as the premier shopping street in the city, linking the so-called Golden Z. The 'bar bell' concept was used to show the way in which Buchanan Street might now serve as a centre of gravity, with retailing to concentrate at the foot of the street and Argyll Street and cultural facilities at the top, along with Sauchiehall Street. Second, a 'string of perils' was to be developed along the Clydeside, to clean, rehabilitate and modernize former run-down port-related land uses. Finally, the M8 motorway was to be used to delimit the CBD to the west of the city with cannons being positioned over the motorway to create a fortress feel.

While the extent to which McKinsey's vision has been transformed into practice is open to question, there can be no doubt that the regeneration of the city centre has been significant. Through a mixture of stone cleaning, floodlighting, better security, pedestrianization and mono-blocking of key streets, and the introduction of a city centre management team, the city centre has been steadily refurbished and the quality of its infrastructure dramatically improved. Serving a catchment area of 2.5 million people, with 3.7 million square feet of retail space, and with employment growing from 94000 to 158000 between 1991 and 2001, Glas- gow city centre is now anecdotally judged to be the second most important retailing centre in the UK outside London.

While the city centre was steadily improving however, critiques of Glasgow's miracle were beginning to be published in the mainstream press. A dual city (or so it was argued) was forming. Beneath the glitz of the revived Golden $\mathrm{Z}$ and the extravagance of the newly gentrified Merchant City in the east of the city centre, socio-spatial polarization remained a key problem. The trickle-down philosophy, it seemed, was doing little to alleviate the plight of residents in deprived inner city cores and in the peripheral housing estates towards the edge of the city. The city's faith in culture-led place marketing was ill founded. Glasgow was miles better, but only for some - those able to cash in on the rebirth of the city centre as a post-industrial service centre.

In 1990, 'Workers City', a loose, leftist and anarchist group, was formed to contest the new Glasgow. While perhaps unrepresentative of general public opinion, Workers City did crystallize a number of concerns which were becoming central to the political climate of the times. The Labour Party were criticized for selling out on the city's socialist heritage and prostituting the city for the consumer dollar. The organic culture of the city was being replaced by a populist and on occasions elitist culture which bore no resemblance to the city's working-class roots. What scarce public funds were available were being transferred from the provision of welfare relief to promoting speculative high-profile marketing projects which were doing little to arrest social and spatial inequalities in the city. What capital was coming into the city was going to the city centre. The volume of investment in the city centre in any case was being overstated. What jobs had been created were poorly paid, weakly unionized and flexible, to the detriment of the worker. There was little to be gained from turning welders into waiters. Regeneration had failed to reach the most needy sections of the Glasgow population (Damer 1990; Paddison 1993; Mooney 2004).

\section{The political economy of planning policy: working with the market to secure balanced growth}

The protocols and practice of planning are always rooted in particular political and economic contexts. Not surprisingly then, a new rapprochement is taking place between neoliberalism and planning 
in the city. Under the Keynesian state, Glasgow of course was once planned as part of the now abolished Strathclyde Regional Council Structural Plan. Strong command planning at a regional scale predominated. To be sure, an accommodation with capital was always present and false lines of demarcation can perhaps be drawn retrospectively. But an ethos of regulation, control and enforcement was not uncommon. Capital was to be moulded into a pattern of land use that the state believed to be the most efficient and egalitarian structure.

Planning now aligns itself with market forces; instead of regulating and controlling the market, planning seeks to work with the market, accommodating investment and adapting to new developments. The days of dictating to developers are now over; at most, planning prods and pokes capital in certain directions while at worst it invents a series of aftercare tools and seeks post-hoc legitimation of trends which were going to happen anyway. While true to differing degrees for planning for housing, industrial, commercial infrastructural and recreational land uses, in the new post-industrial economy it is in the area of retail that the new face of planning is to be most clearly found.

As noted above, Glasgow city centre, and more specifically land, property and leisure and retail capital, emerged as the primary beneficiary of the city's move towards a local economic policy. Steadily however, the fate of the city centre has become caught up in local debates about the importance of promoting spatial planning and balanced growth across the conurbation. These debates have been driven by irresistible development pressures but have a planning rationale also. While remaining the dominant retail space in the west of Scotland, the city centre threatens to become a casualty of neoliberal trends in planning, highlighting the dramatic ways in which neoliberalism has the potential to creatively destroy spaces and landscapes which it has only recently deposited. Neoliberalism intensifies competition between capitals and not just between capital and labour or capital and the state.

And yet NPPG8, the national planning advisory guideline for retail planning, explicitly sets out to defend town centres. The so-called 'sequential approach' is designed to make it steadily harder to secure new planning permission for retail investments the further away from the city centre one gets. Pipeline data on retail developments in Scotland however tell a different story, and it is clear that NPPG8 has not diminished the appetite of investors to seek out-of-town locations (Scottish Ex- ecutive 2004a). Planning applications currently being considered in particular are clearly skewed to out-of-town locations. In addition, while the sequential approach has delivered a better balance of planning consents, it is still the case that out-oftown consents and developments under construction out of town predominate.

In January 2004, the Scottish Executive (2004a) published a comprehensive review of retail planning in Scotland. This document is written against the backdrop of three broader policy agendas that announce a decisive shift beyond the political focus on the city centre that was the hallmark of the 1980s and 1990s in favour of balanced development and edge-of-town and out-of-town retail developments. The special attention once given to the city centre is now tempered by political interest in:

- fostering greater spatial competition within the retail sector in recognition of the importance this sector plays in the Scottish economy;

- encouraging the regeneration of peripheral housing estates, including addressing the problem of retail deprivation in these areas;

- dealing with traffic congestion and promoting sustainable transport solutions for Glasgow city centre.

At first sight, the review does appear to be supportive of the city centre; it is keen to continue with the sequential approach, it advocates a strengthening of town centre management, it calls for the establishment of a national fund to support town centre vitality, and it defines more sharply where town centres end and edges of centres begin. All of this protective work however is undone when the report proceeds to widen out the definition of 'town centre' and admits the possibility that various parts of cities might qualify for town centre status. While the review labours the point about how rigorous planners need to be when establishing a new definition of 'centre', a central contradiction thus permeates the text; existing town centres are to be promoted but competitor edge-of-town and out-oftown sites are to be allowed to be renamed 'centres' and enjoy the same benefits.

A policy of balanced development then is being officially sanctioned and polycentric retail hierarchies in the city and beyond are emerging and consolidating as a consequence:

This study has made various references to the future growth of urban areas in Scotland ben- 
efiting from a pattern of inter linked sustainable centres which assist in providing the best quality of mixed provision in accessible locations. This approach to 'polycentric' urban areas suggests a new approach which embraces a more positive policy towards multiple locations, particularly in large urban areas. This moves away from the 'mono-centric' tone of the previous NPP 8 guidance. It suggests that future planning guidance can move from looking at a notional single town centre to a broader context of sustainable, accessible, and viable urban centres of importance which will make a positive contribution to urban planning objectives.

(Scottish Executive 2004a, p. 115)

A number of structural shifts are likely to occur in the Scottish retailing sector which will undoubtedly serve to further stiffen competition for the city centre in future. In his review of retailing in Scotland between 2000 and 2015, John Dawson (2000) notes that retail sales in Scotland have grown from $£ 13$ billion in 1994 to $£ 17.1$ billion in 1998 and to $£ 19$ billion in 2000. Dawson expects this to continue and for sales to grow to in excess of $£ 26$ billion by 2010 and $£ 30$ billion by 2015 . This suggests that Glasgow city centre has a prosperous future to look forward to.

Nevertheless, according to Dawson (2000):

1 The total number of shops in existence in Scotland will decline from 22500 (today) to fewer than 18000 by 2015 .

2 A more concentrated market will mean that ten retailers will account for over 60 per cent of retail sales. Around forty firms will dominate the market.

3 Many of the leading firms controlling the market will be headquartered outside Scotland and some outside the UK.

4 E-tailing (in a variety of forms) will grow from around 6 per cent today to over 12 per cent of all retail sales by 2015 , accounting for nearly 50 per cent of the increase in sales expected between 2000 and 2015.

5 Independent retailers will be present but in fewer numbers than today.

6 In the light of all of the above, the amount of retail floor space required by 2015 will be less than that available today.

The rise of a centralizing corporate sector, with more power being concentrated in fewer hands, and fewer Scottish hands, garnering more muscle over property owners, carries potentially significant implications for Glasgow city centre. The growth of etailing will further diminish the need for city centre space and will free up retailers from the ties that bind them to landlords even further.

How might Glasgow city centre cope with the new competitive environment in which it now finds itself? While lobbying to contest edge-of-town and out-of-town planning applications will remain an area of political activity for some city centre property owners, a parallel strategy seeking to improve the ability of the city to compete with the edge-oftown and out-of-town environments has emerged. In order to enhance the city centre's competitiveness through improved management, marketing and maintenance, the City Council in association with Scottish Enterprise Glasgow, the Chamber of Commerce and the Glasgow Call Centre Association established the City Centre Partnership - eventually called the City Centre Vision (CCV). The CCV has four key aims:

- to coordinate and improve service delivery in the city centre;

- to articulate business needs to the public sector;

- to promote investment;

- to coordinate marketing and events with business in the city centre.

Despite its entrepreneurial intentions, the Glasgow CCV has had little impact in cultivating the 'business atmosphere' that its members hoped for. The organization disbanded and was subsequently assimilated into what is now the Glasgow City Centre Action Plan (GCC 2006).

New legislation was then introduced in 2005 to transplant North American solutions known as Business Improvement Districts (BIDs) into the UK (Ward 2006). BIDs normally refer to a geographically defined space in a city in which local businesses agree to pay an additional local tax which is then spent directly on improving the local business environment. The arrival of BIDs in the United Kingdom announces a new intra-regional as opposed to inter-city - competition for a role in the spatial division of consumption; town centres are now competing with their hinterlands as much as they are with other town centres.

In August 2003 a consultation paper was issued by the then Minister of Finance and Public Services, Andy Kerr, in regard to establishing BIDs in Scot- 
land (Scottish Civic Forum 2003). In April 2004 the Scottish Executive (Scottish Executive 2004b) published an analysis of responses to the above consultation paper (Scottish Civic Forum 2003). In principle a BID proposal "would only work if there was a clear need for additional services and the benefits to the businesses paying the levy were clearly identifiable' (Scottish Executive 2004b, p. 3). These initial concerns did not act as an impasse to the Scottish Executive who passed legislation to establish six BID pilot areas in Clackmannanshire (Alloa, Tillicoultry and Alva), and Bathgate, Edinburgh, Falkirk, Glasgow and Inverness city centres.

For critical human geographers such as Mitchell (2003) and Smith (1996), BIDs encourage zero-tolerance policing that is in reality a form of 'revanchist' urbanism. BIDs are susceptible to the Conservative 'Broken windows theory' (Wilson and Kelling 1982) and its visceral zero-tolerance approach to crime whereby smaller crimes must not be tolerated because they automatically lead to more serious crimes. There is a danger that some social groups will be 'cleansed' from a 'sanitized' public space so as to make this space more appealing to tourists and local businesses. The relevance of these arguments in Glasgow remains unclear. While Glasgow city centre is far from being a revanchist space at present, it is also far from functioning as a truly public space also (Scottish Civic Forum 2003).

\section{Welfare policy: in search of social cohesion and sustainable communities}

Pivotal to emerging welfare policy is the need to manage and discipline those disenfranchised by earlier waves of neoliberalism - the casualties of the Thatcher and Reagan periods for whom trickledown was little more than an empty buzz-word. Communities suffering from endemic poverty and deprivation are now to be the focus of attention. Neither the welfare state in the 1945 to 1973 period, nor Thatcher and Reagan's resort to the market in the period from 1979, have proven capable of addressing problems which are now to be defined as 'social exclusion'. Communities need to be made more sustainable and a new approach to their governance is required.

In spite of its reputed post-industrial renaissance, socio-spatial poverty, exclusion, inequality and deprivation remain persistent and enduring problems in Glasgow. By the mid-1990s, Glasgow City Council had accepted that it alone could not tackle the deeply ingrained social-spatial problems which remained in some inner city neighbourhoods and most peripheral housing estates. It was at this juncture that "capacity building' and 'partnership working' entered the local lexicon with a sense of urgency that was hitherto lacking. Governance was to replace government as the motif behind regeneration approaches. This move was to be fortified and developed by the election of New Labour in 1997 and the formation of the New Labour-controlled Scottish Parliament and Scottish Executive in 1999.

Arguably, the first major expression of the new emphasis upon partnership working came with the establishment of Glasgow Regeneration Alliance (GRA) in 1995. GRA comprised a partnership between the then Strathclyde Regional Council (now abolished), Glasgow District Council, Glasgow Development Agency (now Enterprise Glasgow) and Scottish Homes (now Communities Scotland). Its main aim was to encourage key urban agencies to work together more formally, in particular to bring about a more coherent regeneration of deprived neighbourhoods. Little, however, was achieved by the GRA in terms of concrete policy formulation, meaningful coordination and the enlisting of long-term commitment from partners (Glasgow Alliance 1999).

In coming to power in 1997, New Labour's Secretary of State for Scotland and First Minister for Scotland, Donald Dewar, became critical of the lack of coherence which marked Glasgow's approach to urban regeneration and combating sociospatial exclusion. In 1998 Dewar decided to rename and relaunch GRA as the Glasgow Alliance. The membership base was to be expanded to include: Glasgow City Council, Enterprise Glasgow, Greater Glasgow Health Board, Communities Scotland, Scottish Business in the Community, and finally Glasgow Council for the Voluntary Sector. The Scottish Executive was to be represented by the Chief Planner for Scotland. While some new funds were made available for the new Alliance, Dewar made it clear that no significant funds would be provided for the city. The central panopticon of the Scottish Executive was to exercise more surveillance over Glasgow's partnership model and its workings.

A major review of Glasgow Alliance conducted by private consultants Rocket Science UK Ltd (2004) highlighted the lack of progress the partnership was making. Once again the difficulties of getting partners to see beyond their own remit, to bend resources into areas of greatest need, and to commit to long-term partnership structures and projects 
Table 1. Community Planning Partnerships and emerging welfare policies.

\begin{tabular}{ll}
\hline Dominant development/policy logic & Process/outcome \\
\hline $\begin{array}{l}\text { Fordist-Keynesian welfare state in part sought a 'bricks-and- } \\
\text { mortar' solution to urban regeneration leading to dramatic }\end{array}$ & $\begin{array}{l}\text { Serialized landscapes created, populated by communities of de- } \\
\text { spair, wastage, withdrawal and disengagement. }\end{array}$
\end{tabular}
physical transformation of the city landscape.

Neoliberal approaches have further intensified social polarization and the trickle-down philosophy has failed to deliver for disadvantaged communities.

The new approach recognizes that state intervention is necessary to address failure of unfettered neoliberalism.

State intervention designed to foster community rehabilitation to enable communities to stand on their 'own two feet', reproducing themselves autonomously in the market economy.

To instil active citizenry attention needs to focus on rebuilding local social capital - taken loosely to refer to the vibrancy, intensity and inclusivity of local social networks.

Intervention, in various guises, is important to foster and nurture social capital.

State intervention seeks to maximize the abilities of communities to be self-sustaining (and self-reliant) and which deals with social exclusion by seeking to mainstream otherwise disenfranchised neighbourhoods.
Marginalization, anomie, alienation and exclusion have deepened.

Policies designed to address urban deprivation and avoid creating a climate of welfare dependency.

In return for state intervention, communities are expected to comprise active citizens; welfare is to give way to workfare.

Greater social capital is presumed to be the midwife of increased participation and the formation of more sustainable communities.

Interventions such as improved urban design, pursuit of social mixing, skills mixing/training, community empowerment and an enhanced role for the voluntary sector.

Policies such as Community Planning Partnerships designed to intervene in ways which minimize future welfare dependency and promote an inclusive society and a more active citizenry. was documented. This diagnosis of the limitations of Glasgow Alliance coincided with the introduction of the Local Government (Scotland) Act 2003 promoting a Community Planning Agenda. The result of the report led to Glasgow Alliance being renamed Glasgow Community Planning Ltd in 2004 and becoming the support body for the new Glasgow Community Planning Partnerships which have emerged in the city.

Community Planning Partnerships embody perfectly New Labour's wider Third Way approach to urban policy. They are based upon a collection of arguments which seek to steer a middle course between Fordist Keynesian (state interventionist) and neoliberal (free-market) positions:

rather than leaving neighbourhoods to the operation and efforts of the property and labour markets, or intervening as a nanny state to shore up failing enterprises...the notion is that self-help activities undertaken within existing market and governmental structures is the way forward for disadvantaged groups and communities.

(Imrie and Raco 2003, p. 13)
In skeletal form, these arguments are summarized in Table 1. The role of Community Planning Partnerships is to intervene in ways which minimize further welfare dependency and which maximize the abilities of communities to be self-sustaining, and which deals with social exclusion by mainstreaming otherwise disenfranchised neighbourhoods (Deas 2005).

It is against the backdrop of the formation of Community Planning Partnerships that community planning has been extended in specific areas of service provision in the city. Wholesale changes, for instance, are taking place in the ownership and governance of social housing in Scotland. At the heart of these changes is the so-called stock transfer process, whereby central control over social rented housing has given way to community ownership and self-governance. In 2003, Glasgow City Council transferred over 80000 houses to the newly formed Glasgow Housing Association. The formation of Glasgow Housing Association was always intended to be a stepping stone in the stock transfer process, with the eventual goal being the dissolution of the organization and the further decentralization of governance over social housing to some 
sixty-six Local Housing Organizations. Only by getting closer to communities might the ultimate goal of radical community ownership and planning be attained. At present, the intention is to substantially complete this second stage of transfer by 2010.

Likewise NHSScotland is currently undergoing a transformation which is designed to re-emphasize local solutions to local health problems. As part of this 'return to the local', a patchwork quilt of new Community Health Partnerships (CHPs) are being created across the country. With a greater degree of power and resources now devolved down to CHPs, it is hoped that community empowerment will encourage a renewed interest in community planning and that disadvantaged neighbourhoods will design their own, locally tailored solutions to the problem of health inequalities. CHPs are expected to work with other health professionals, including general practitioners, dentists, pharmacists and opticians, to plan and develop services across the CHP area. Foregrounding the importance of anticipatory as well as medical intervention, they are also expected to enter into multi-agency partnerships and to improve integration of the National Health Service, local authority and voluntary sector service provision.

According to Imrie (2004), Fyfe (2005) and May et al. (2005), while professing a deep commitment to equality of opportunity and local empowerment, welfare approaches in these guises is best approached in terms of Foucault's concept of 'governmentality'. The transition from government to governance and now to governmentality has been substantially completed. Community Planning Partnerships serve as a new kind of normative communitarian discourse shaping the "conduct of conduct': reifying concepts such as 'sustainable communities', 'social capital', 'quality of life' and 'active citizenship'; introducing new infrastructures of intervention and a new community of regeneration professionals and associated practitioner literature; and promoting new measures and metrics of evaluation. In turn, these instruments of governmentality are exercising a strong disciplinary force on local communities, making use of a convoluted apparatus of rewards and penalties to impose moral assumptions about which forms of community are 'good' and 'bad'/'right' and 'wrong'/'just' and 'unjust'/'worthy' and 'unworthy', and to establish the first contours of a new 'shadow state'.

The sustainable communities agenda seeks to promote a reconstitution of relations between the state and disadvantaged communities in ways which aim to serve rather than penalize capital. The state can help but communities themselves need to learn that irresponsible behaviour exacts a cost for which someone has to pay. Residents need to address their own 'failings' and 'weaknesses' which result in such social 'ills' as welfare dependency, benefits fraud, truancy, teenage pregnancy, singleparent families, graffiti and vandalism, antisocial behaviour, substance abuse and alcoholism, obesity, poor diet, and lack of exercise. Therein, the social consequences and casualties of neoliberal economic reform come to be codified and managed in a way that appears to be supportive and relatively benign.

\section{Conclusion}

In spite of dire predictions and apocalyptic forecasts, neoliberalism has shown itself to be a tenacious animal. According to David Harvey, neoliberalism's record of securing economic growth has been 'dismal', comparing unfavourably to Keynesianism in its prime. However, it has been hugely successful in temporarily staving off the falling rate of profit and crises in capital accumulation which prevailed in the mid-1970s. In so doing, its main achievements have been 'redistributive rather than generative' (Harvey 2006, p. 153). For Harvey, neoliberalism is best conceived of as a political project designed to restore class power by returning the division of the national product between competing class fractions back to pre-Keynesian levels. This reredistribution has been managed by the introduction of new forms of 'accumulation by dispossession', including the privatization and commodification of virtually everything everywhere, financialization, the management and manipulation of crises, and state redistributions.

But how has neoliberalism managed to sustain, legitimate, and even entrench accumulation by dispossession? While recognizing the variegated strains of the 'neoliberal virus' which exist in different historical and geographical settings, and dubbing teleological readings of neoliberalism's trajectory 'politically complacent and theoretically erroneous', Peck and Tickell (2002) provide a useful overview of the genesis, diffusion and evolution of neoliberalism in advanced capitalist nations. In so doing they mobilize the notions of roll-back neoliberalism and roll-out neoliberalism.

As early as 1994 and ahead of many commentators, Peck and Tickell concluded that roll-back neo- 
liberalism could not serve as a new regulatory fix and was unsustainable. By the early 1990s it appeared that the "politics of crises were working their natural course' (Peck and Tickell 2002, p. 386). Roll-back neoliberalism was merely serving to deepen and exacerbate crises, by, for example, intensifying economies' vulnerability to volatile cycles of boom and bust, intensifying social and spatial polarization, deepening inter-locality competition for roles in the spatial division of labour and consumption, and silencing socially progressive alternatives. The state was in danger of slipping into a condition of endemic crisis, and a crisis in crisis management was itself to be expected (Jones and Ward 2002).

Beginning in the early 1990s when Thatcherism and Reaganism were showing clear signs that they had run their course, a second stage of neoliberalism then emerged. Articulated most clearly by the Clinton and Blair projects, this mutation has invariably been presented as an alternative to neoliberalism and in the United Kingdom at least has been given the title the Third Way. Far from being an innovation however, for Peck and Tickell the Third Way is little more than a flanking support for neoliberalism - a form of roll-out neoliberalism in which the state is permitted a more aggressive role.

The Third Way has sought to stabilize neoliberalism by reconstituting relations between the state and the market. According to Peck and Tickell (2002), neoliberalism has shifted from the 'law of the jungle' to the much more purposeful construction of market rules. Neoliberalism no longer calls for a withdrawal of the state but instead prioritizes a reconstitution of the terms within which states might intervene. New state architectures are to be erected to buttress, underpin, coerce and jockey the market. The overriding objective is to direct market relations so as to produce more socially useful outcomes. More usually, however, state intervention seeks to benefit the needs of capital first and foremost:

Forms of shallow neoliberalisation - during the Thatcher/Reagan years - that were understood by many at the time as a moment of destructive and reactionary anti-regulation might now need to be confronted as a more formidable and robust pattern of proactive statecraft and pervasive - meta regulation. Granted, it may still be (politically) inappropriate to regard the contemporary manifestation of neoliberalisation as a form of regulato- ry settlement but its multi-faceted development during the 1990s and beyond surely calls for more sharply focussed analyses both of actually existing neoliberalisms and of the force fields in which they are embedded.

(Peck and Tickell 2002, p. 387)

If the various forms of roll-out neoliberalism which are being piloted in capitalist cities are to undergird market rule and secure for capitalism a regulatory framework of some durability, it would seem important to scrutinize more closely their manifestations and functioning in different cities. In this article, attention has been given to the rolling out of neoliberalism in the city of Glasgow. A longitudinal survey has been presented, tracking changes in economic policy, spatial planning and welfare provision across the period 1977 to the present.

To be sure, something new and distinctive has occurred in the city. If demand management was the chief economic policy under Keynesianism, it is clear that local economic policy in Glasgow has focused on supply-side measures. If regulatory planning and development control was the hallmark of planning under Keynesianism, then it is clear that flexible planning and working with and around market trends is the new rule. If welfare provision under Keynesianism focused upon the mass provision of collective consumption and the reproduction of labour power, then today, workfare, the disciplining of welfare recipients and customer-led service provision form the backbone of a new approach.

Nevertheless, we have chosen to insist upon the messiness of neoliberalism's grounding in Glasgow and to prioritize the actually existing forms it has taken. In Glasgow, neoliberalism has interlaced with historical structures, ideologies and policies with particular path trajectories to produce a complex series of hybrids which at times do not look particularly neoliberal at all. It perhaps makes sense to refer to them collectively as 'roll-out neoliberalism' but even here caution must be exercised. While recognizing the potential abuses which are risked by continued usage of the label, we have chosen to retain it here in a qualified form, to denote the broad spirit and direction of change which has occurred within the city. Something distinctive has been working on the institutions governing the city and, while not capturing these institutions, has contributed in a fundamental way to their metamorphoses. If conceived of as a force for reform which manifests itself to different degrees 
in different policy sectors in different cities, there remain both conceptual and political advantages from the continued usage of neoliberalism in the academic lexicon.

We conclude by noting that precisely because of the contingent and complicated forms it deposits, many of them bearing the imprint of their heritage more so than neoliberalism per se, roll-out neoliberalism will continue to struggle to secure a regulatory framework capable of stabilizing local accumulation indefinitely. Moreover, central to judgements about the regulatory power of roll-out neoliberalism must be an evaluation of the different spatialities which different neoliberalisms produce. Actually existing neoliberal urbanism in fact produces different spatial outcomes and because it does not amount to a pure and coordinated project these spatial outcomes contract and collide as often as they reinforce.

The three policy areas examined in this article have been shown to produce three different sociospatial formations which overlap in complex ways:

1 Public subsidy of place-marketing projects designed to promote post-industrial factions of capital and in particular a thriving and profitable downtown.

2 Planning interventions seeking to create polycentric urban development and therein prioritizing the interests of property capital keen to invest in out-of-town locations, disadvantaged communities on the periphery of the city, and transport and environmental sustainability.

3 Public-led partnerships scaled at community levels aspiring to foster social capital and to reintegrate disadvantaged neighbourhoods back into the mainstream.

The neoliberalization of urban governance is best thought of as secreting a series of mutant socio-spatial landscapes, the spatiality of which is not incidental to regulatory effectiveness. The challenge will be to trace through the aggregate effects - both reinforcing and undermining - of actually existing neoliberalism's different socio-spatial forms so as to better understand where and when they combine to strengthen or weaken local regimes of accumulation.

\section{Acknowledgement}

The authors would like to thank Ann McDowell for her helpful comments on an earlier draft of this article.

\section{Mark Boyle}

Department of Geography

National University of Ireland, Maynooth

Co. Kildare, Ireland

E-mail: mark.g.boyle@nuim.ie

\section{Christopher McWilliams}

School of the Built Environment

Heriot-Watt University

Edinburgh, EH14 4AS

United Kingdom

E-mail: C.McWilliams@hw.ac.uk

\section{Gareth Rice}

Department of Geography

University of Helsinki

P.O. Box 64

FIN-00014 Helsinki, Finland

E-mail: gareth.rice@helsinki.fi

\section{References}

BIANCHINI, F. and PARKINSON, M. (eds) (1993): Cultural Policy and the Urban Regeneration Experience: The West European Experience. Manchester University Press, Manchester.

BOYLE, M. and HUGHES, G. (1994): 'The politics of urban entrepreneurialism in Glasgow', Geoforum 25 (4): 453-470.

BRENNER, N. and THEODORE, N. (eds) (2002): Spaces of Neoliberalism: Urban Restructuring in North America and Western Europe. Blackwell, Malden, MA.

BRENNER, N. and THEODORE, N. (2005): 'Neoliberalism and the urban condition', City 9 (1): 101-107.

CHECKLAND, S. (1976): The Upas Tree: Glasgow 1875-1975. A Study in Growth and Contraction. University of Glasgow Press, Glasgow.

DAMER, S. (1990): Glasgow: Going for a Song. Lawerence \& Wishart, London.

DAWSON, J. (2000): Trends in Retailing in Scotland, 20002015. Scottish Executive, Edinburgh.

DEAS, I. (2005): 'Synchronization, salesmanship and service delivery: urban governance and economic competitiveness', in BUCK, N., GORDON, I., HARDING, A. and TUROK, I. (eds): Changing Cities: Rethinking Urban Competitiveness, Cohesion and Governance. Palgrave Macmillan, Basingstoke, pp. 204-222.

FYFE, N.R. (2005): 'Making space for "neo-communitarianism"? The third sector, state and civil society in the UK', $A n$ tipode 37 (3): 536-557.

GCC (2006): Glasgow City Centre Action Plan. Glasgow City Council, Glasgow.

GLASGOW ALLIANCE (1999): 'Creating tomorrow's Glasgow'. Glasgow Alliance, Glasgow.

HACKWORTH, J. and MORIAH, A. (2006): 'Neoliberalism, contingency and urban policy: the case of social housing in Ontario', International Journal of Urban and Regional Research 30 (3): 510-527.

HARVEY, D. (1989): 'From managerialism to entrepreneurialism: the transformation of governance in late capitalism', Geografiska Annaler: Series B, Human Geography 71 (1): 317. 
HARVEY, D. (2005): A Brief History of Neoliberalism. Oxford University Press, Oxford.

HARVEY, D. (2006): 'Neo-liberalism as creative destruction', Geografiska Annaler: Series B, Human Geography 88 (2): 145-158.

IMRIE, R. (2004): 'Urban geography, relevance, and resistence to the "policy turn" ', Urban Geography 25 (8): 697-708.

IMRIE, R. and RACO, M. (eds) (2003): Urban Renaissance? New Labour, Community and Urban Policy. Policy Press, Bristol.

JONES, M. and WARD, K. (2002): 'Excavating the logic of British urban policy: neoliberalism as the "crisis of crisis-management", , Antipode 34 (3): 473-494.

MACLEOD, G. (2002): 'From urban entrepreneurialism to a "revanchist city"? On the spatial injustices of Glasgow's renaissance', Antipode 34 (3): 602-624.

MAY, J., CLOKE, P. and JOHNSEN, S. (2005): 'Re-phasing neoliberalism: New Labour and Britain's crisis of street homelessness', Antipode 37 (4): 703-730.

MCKINSEY and CO.(1984): The Potential of Glasgow City Centre. Scottish Development Agency, Glasgow.

MITCHELL, D. (2003): The Right to the City: Social Justice and the Fight for Public Space. Guilford Press, New York.

MOONEY, G. (2004): 'Cultural policy as urban transformation? Critical reflections on Glasgow, European City of Culture 1990', Local Economy 19 (4): 327-340.

MOONEY, G. and DANSON, M. (1997): 'Beyond "Culture city": Glasgow as a "dual city" ', in JEWSON, N. and MACGREGOR, S. (eds): Transforming Cities. Routledge, London, pp. 73-86.
PADDISON, R. (1993): 'City marketing, image reconstruction and urban regeneration', Urban Studies 30 (2): 339-349.

PECK, J. and TICKELL, A. (2002): 'Neoliberalizing space', Antipode 34 (3): 380-404.

ROCKET SCIENCE (2004): Review of the Glasgow Alliance. Rocket Science UK Ltd, Edinburgh.

SCOTTISH CIVIC FORUM (2003): Consultation on Business Improvement Districts in Scotland. Scottish Executive, Edinburgh.

SCOTTISH EXECUTIVE (2003): Local Government in Scotland Act 2003. Scottish Executive, Edinburgh.

SCOTTISH EXECUTIVE (2004a): Research Study on the Effectiveness of NPPG 8: Town Centres and Retailing. Development Department, Scottish Executive, Edinburgh.

SCOTTISH EXECUTIVE (2004b): Business Improvement Districts: A Consultation. Analysis of Responses to Consultation. Scottish Executive Finance and Central Services Department, Edinburgh.

SENNETT, R. (2003): Respect: The Formation of Character in an Age of Inequality. Allen Lane, London.

SMITH, N. (1996): The New Urban Frontier: Gentrification and the Revanchist City. Routledge, New York.

TUROK, I. (2004): 'Cities, regions and competitiveness', Regional Studies 38 (9): 1069-1083.

WARD, K. (2006): "'Policies in Motion", urban management and state restructuring: the trans-local expansion of business improvements districts', International Journal of Urban and Regional Research 30 (1): 54-75.

WILSON, J.Q. and KELLING, G.L. (1982): 'Broken windows', Atlantic Monthly 127 (3): 29-38. 